\title{
Neuroinflammation and M2 microglia: the good, the bad, and the inflamed
}

\author{
Jonathan D Cherry', John A Olschowka ${ }^{1}$ and M Kerry O'Banion²
}

\begin{abstract}
The concept of multiple macrophage activation states is not new. However, extending this idea to resident tissue macrophages, like microglia, has gained increased interest in recent years. Unfortunately, the research on peripheral macrophage polarization does not necessarily translate accurately to their central nervous system (CNS) counterparts. Even though pro- and anti-inflammatory cytokines can polarize microglia to distinct activation states, the specific functions of these states is still an area of intense debate. This review examines the multiple possible activation states microglia can be polarized to. This is followed by a detailed description of microglial polarization and the functional relevance of this process in both acute and chronic CNS disease models described in the literature. Particular attention is given to utilizing M2 microglial polarization as a potential therapeutic option in treating diseases.
\end{abstract}

Keywords: alternative activation, M2, microglia, neuroinflammation

\section{Background}

For the better part of a century, the function of microglia in the central nervous system (CNS) was a topic wrapped in controversy. Originally identified by Franz Nissl in 1899 as 'Stabchenzellen' or rod-like cells, and further classified by Pío del Río Hortega in 1919, these cells were determined to be a distinct non-neural and non-astrocytic population [1]. Furthermore, Hortega's observations suggested a capacity for phagocytosis, indicating that these cells were more than just space filler or connective cells between neurons. Not all shared Hortega's ideas. This included his mentor, the father of modern neuroscience, Ramón y Cajal, who urged Hortega not to publish and subsequently fired Hortega [2]. This early turmoil set the tone for decades to follow, during which the topics of microglial functions and origins were extensively debated [3]. However, beginning in the early 1980s, newer technology and ideas began to reveal the true nature of microglia as the brain's resident immune cell. Even though we are starting to understand what microglia are capable of, many questions still remain. In particular, there is much to

\footnotetext{
* Correspondence: Kerry_OBanion@urmc.rochester.edu

${ }^{2}$ Department of Neurobiology \& Anatomy, University of Rochester School of Medicine and Dentistry, Rochester, NY 14642, USA

Full list of author information is available at the end of the article
}

be learned about the plastic nature of these cells and the functions served by different microglial phenotypes.

In agreement with Hortega's original description, microglia have been classically described to exist in two states, resting and activated. However, this binary definition has since been revised to make way for more complex ideas. Microglia in the healthy CNS are not truly 'resting'. Twophoton microscopy has shown microglia to be engaged in environmental surveillance, constantly sampling areas around them in efforts to maintain homeostasis [4]. Once microglia encounter a substance that they sense is foreign or indicative of harm, they enter an 'activated' state. As macrophage-like cells of the brain, one of the main roles of activated microglia is that of regulating CNS innate immunity and initiating appropriate responses, such as inflammation. In the brain, this inflammatory response, termed neuroinflammation, is a fundamental response generated to protect the CNS; however, uncontrolled or prolonged neuroinflammation is potentially harmful and can result in cellular damage. This is particularly relevant to neurodegenerative diseases, which are typified by evidence of microglial activation and neuroinflammation [5]. This makes microglial activation an attractive target to study as part of disease pathogenesis.

The term activation is an oversimplification of a range of different 'activated' states. It is now recognized that 
activated microglia can exist broadly in two different states [6]. The first is classical activation, which is typified by the production of inflammatory cytokines and reactive oxygen species, while the second is a state of alternative activation, in which microglia take on an anti-inflammatory phenotype involved in wound repair and debris clearance [7]. It stands to reason that during neurodegenerative disease, where neuroinflammation is a prominent feature and potential contributor to disease, these alternatively activated microglia would be beneficial in resolving pathology.

The presence of multiple activation phenotypes for microglia is a relatively new concept that is only starting to gain momentum. Therefore, the amount of data is still sparse on the roles they play. However, the activation status of peripheral macrophages has been an area of interest ever since Stein and colleagues observed that interleukin 4 (IL-4) induced macrophages to express the mannose receptor [8]. Such a phenotype was previously unseen and was therefore designated 'alternative'. Since then, multiple laboratories have characterized and classified 'unique' activation states, leading to a somewhat convoluted set of nomenclature. However, recent evidence suggests that the in-vitro data originally used to identify macrophage phenotypes does not accurately model the complex tissue environment and the original descriptions are somewhat simplistic [9]. Moreover, unlike the periphery, in which these cells have been studied for more than 20 years, we are just beginning to closely examine these complicated activation states in the CNS. Therefore, a deeper understanding of the heterogeneity and different phenotypes of microglia is needed; assumptions that information gleaned in the periphery will translate to the brain may not be correct.

\section{Classical versus alternative activation}

Neuroinflammation, and, to the same degree, all inflammation, is a fundamental immune response designed to protect the body from harm, arising from both endogenous and exogenous sources. Being the sentinel immune cell of the brain, microglia are tasked as the first responders to infection or tissue injury and initiating an inflammatory response. Using a full array of immune receptors, such as toll-like receptors (TLRs), nucleotidebinding oligomerization domains (NODs), NOD-like receptors, and many scavenger receptors [10,11], microglia (as well as other CNS cells, such as astrocytes) are able to recognize harmful stimuli and respond by producing inflammatory cytokines such as TNF $\alpha$, IL-6, IL-1 $\beta$, interferon- $\gamma$ (IFN $\gamma$ ), and several chemokines [12]. This cytokine production is essential for the polarization of microglia into what has been termed a classically activated, 'M1', state [13]. This term parallels the Th1 terminology used for $\mathrm{T}$ cells, and underscores the close relationship between $\mathrm{T}$ cells and macrophages in the periphery. Interferon $-\gamma$ produced from Th1 cells was found to be instrumental in polarizing macrophages to M1 [14]. However, the ability to produce these cytokines does not rest solely with T cells. Microglia and astrocytes have also been observed to fill this role [15,16], demonstrating, at least in part, that microglia can control their own polarization through autocrine and paracrine means. In many cases, this response is protective and is downregulated once the damage or pathogen has been dealt with; however, unregulated, long-term, or chronic inflammation can lead to tissue destruction [17].

In contrast with proinflammatory M1 cells, alternatively activated macrophages express cytokines and receptors that are implicated in inhibiting inflammation and restoring homeostasis. This includes production of IL-10 to downregulate inflammatory cells, extracellular matrix protecting proteins like YM1, ornithine, and polyamines for wound repair, and higher levels of receptors associated with phagocytosis, such as scavenger receptors [18]. Just as the Th1 cytokine IFN $\gamma$ has been associated with induction of proinflammatory M1 macrophages, the Th2 cytokine IL-4 has been associated with M2, or alternative, activation. In the periphery, M2 cells are not always associated with protective functions. In addition to parasite protection, wound repair, and debris clearance, these cells are also potential key players in asthma and allergy responses [7]. However, these types of harmful reaction may not be relevant in the CNS, demonstrating a divergence between peripheral and central cells. Interestingly, it appears that when there is a lack of M2 cell differentiation in the CNS, problems can arise (this is discussed in detail later).

\section{Phenotype of M1 cells}

To properly understand the role microglia play in neurodegeneration, understanding their phenotypes is important. The functional effects of classical activation are geared towards antigen presentation and the killing of intracellular pathogens. Therefore, upregulation of many associated receptors and enzymes reflects that purpose. For example, MHC II, CD86, and Fcy receptors are upregulated to allow for antigen-presenting activity of microglia and increased crosstalk with other immune cells [19]. In addition, the ratio of particular cytokines has been used to identify inflammatory macrophages and this observation could extend to microglia. For example, since M1 macrophages were found to be a key source of IL-12 [20], it was suggested that IL$12^{\text {High }}, \mathrm{IL}-10^{\text {Low }}$ production is a simple way to distinguish inflammatory cells [21]. Another potential distinction and an important component of M1 microglia is their ability to produce reactive oxygen species and reactive nitrogen species [22]. A key microglial enzyme associated with this process is inducible nitric oxide synthase (iNOS), which utilizes arginine to produce nitric oxide [23]. However, even though it seems straightforward to identify M1 cells based 
on these characteristics, classifying these cells in vivo has proven to be more challenging, reflecting the plastic nature of microglia.

\section{Phenotype of M2 cells}

There is not one set description or classification of M2 cells. In fact, there are many efforts to identify unique subgroups with different functions. Division of M2 cells is based on observations that stimulation with various cytokines yields different sets of receptor profiles, cytokine production, chemokine secretion, and function [21]. Even though the profiles of these cells are diverse, the one feature that places them all in the M2 classification is that they express mediators or receptors with the capacity to downregulate, repair, or protect the body from inflammation [24].

The original alternatively activated macrophage was classified based on expression of the mannose receptor [8]; since then an assortment of different markers has been identified as 'M2' specific. One of the best characterized markers is the enzyme arginase 1 (Arg1) [25], which converts arginine to polyamines, proline, and ornithines that can contribute to wound healing and matrix deposition [26]. Interestingly, by using arginine, which is the same substrate used by iNOS, Arg1 can effectively outcompete iNOS to downregulate production of nitric oxide $[27,28]$. Thus, iNOS and Arg1 represent a relatively straightforward set of markers to follow M1 versus M2 phenotypes. Other markers used for identifying M2 cells include Ym1, a heparin-binding lectin [29,30], FIZZ1, which promotes deposition of extracellular matrix [31], and CD206, a mannose receptor [8]. A list of additional markers can been found in Table 1. Despite the benefit of having specific markers, using just one or two is limiting and ignores the overall diversity of M2 phenotypes.

Another way to classify the function and phenotype of M2 cells is based on the cytokines that induce them. The prototypical cytokine used to first induce alternative activation was IL-4 [8]. Both IL-4 and the closely related cytokine IL-13 signal through IL-4R $\alpha$ to induce a host of downstream processes that lead to potent anti-inflammatory functions, such as Arg1 upregulation, inhibition of NF- $\mathrm{kB}$ isoforms, and production of scavenger receptors for phagocytosis $[19,47,48]$. This type of activation has been classified as 'M2a'. The main function of this response appears to be suppression of inflammation. A second state of alternative activation is based on macrophages exposed to IL-10, glucocorticoids, or TGF- $\beta$. This phenotype is classified as 'M2c' $[21,49]$. Originally, this state was described as being 'deactivated' but that is not a particularly useful description. Instead of having no function, 'deactivated' M2c macrophages appear to be involved in tissue remodeling and matrix deposition after inflammation has been downregulated [21]. A third sub-class of M2 activation has been observed following exposure to immune complexes and stimulation of TLR. This class is termed 'M2b' or Type II $[21,50]$. Of these three classes, M2b macrophages are the least understood. Interestingly, they more closely resemble M1 macrophages, owing to the lack of any M2 specific markers, such as Arg1, YM1, or FIZZ1. However, they do express the typical IL-10 ${ }^{\text {High }}$, IL- $12^{\text {Low }}$ M2 cytokine profile [9]. Moreover, they have higher levels of MHCII and CD86, suggesting that they retain their ability to stimulate $\mathrm{T}$ cells [50]. Interestingly, it appears that when M2b macrophages stimulate $\mathrm{T}$ cells they are biased towards a Th2 response [51]. Being able to induce Th2 T cells suggests that M2b might be a potential regulator or initiator of the M2 response in general. One additional type of M2 activated cell, the so-called tumor-associated macrophage, has recently been recognized [52]. Although tumor-associated macrophages are an area of intense research [53], they are beyond the scope of this review. An important consideration regarding M2 phenotypes is that these states were typically elucidated in vitro following exposure to one or two stimuli. This does not represent the complex environmental milieu seen in tissue. Therefore, some investigators have cautioned against this classification into distinct subtypes and instead propose that M2 cells should be viewed as a spectrum of phenotypes [9].

This detailed classification of M2 cells has been primarily carried out in the periphery. Whether or not this will extend to brain resident microglia is yet to be seen. However, some investigators have taken to using the M2a-c nomenclature to discuss populations of alternatively activated microglia [54]. This poses potential problems, as certain M2 markers do not appear to be expressed in the CNS (Table 1). The best example of this is the first observed alternative macrophage marker, CD206, which is only seen in perivascular or choroidplexus-associated macrophages and not expressed by parenchymal microglia [55]. Furthermore, microglia are not macrophages that migrate into the brain, but instead are known to represent a distinct population of resident tissue mesenchymal cells that populate the CNS during early development $[56,57]$. Importantly, because the origins and responses of microglia and macrophages are different, the roles they play in mitigating or propagating pathology could be different as well.

\section{M2 microglial activation during acute neuroinflammation}

In mechanical injuries like spinal cord and traumatic brain injury or other relatively acute conditions like ischemic reperfusion injury, released damage-associated molecular patterns (DAMPs) induce the innate immune system to activate and produce inflammatory cytokines and reactive oxygen species [58-60]. As previously stated, this response is not purposefully harmful. In fact, it is a necessary step in wound repair [61]. The initial proinflammatory response is 


\section{Table 1 M2 markers}

\begin{tabular}{|c|c|c|c|c|}
\hline M2 marker & Function & Expressed in murine microglia? & Expressed in human microglia? & Reference \\
\hline Arginase 1 (Arg1) & $\begin{array}{l}\text { Converts L-arginine into prolines and polyamines implicated } \\
\text { in tissue remodeling and wounding healing. It competes } \\
\text { with iNOS for substrates. }\end{array}$ & Yes & $\begin{array}{l}\text { Debated: evidence suggests it is not upregulated } \\
\text { in human beings but others have shown } \\
\text { elevations in the CNS. }\end{array}$ & {$[6,27,28,32,33]$} \\
\hline Ym1 (Chi3|3) & $\begin{array}{l}\text { A secretory lectin that binds heparin/heparan sulfate. } \\
\text { It is proposed to prevent degradation of extra } \\
\text { cellular matrix components. }\end{array}$ & Yes & $\begin{array}{l}\text { Similar to arginase } 1 \text { as it has been seen in } \\
\text { human beings. However, it might not be } \\
\text { expressed in M2 microglia. }\end{array}$ & {$[6,30-33]$} \\
\hline FIZZ1 (Retn|B) & $\begin{array}{l}\text { Mediates interactions between sensory nerves and } \\
\text { inflammatory cells in the lungs. It blocks nerve } \\
\text { growth factor induced survival of dorsal } \\
\text { root ganglion neurons. }\end{array}$ & Yes & Unknown & {$[31,34,35]$} \\
\hline MRC (CD206) & Binds and internalizes/phagocytoses mannosylated ligands. & $\begin{array}{l}\text { No, limited to perivascular } \\
\text { macrophages and meninges }\end{array}$ & Observed in vitro. & {$[36-38]$} \\
\hline CD163 & Binds and internalizes hemoglobin-haptoglobin complex. & Yes & Yes & [39-41] \\
\hline TREM2 & $\begin{array}{l}\text { The endogenous ligand is unknown, but thought } \\
\text { be involved in debris clearance. }\end{array}$ & Yes & Yes & {$[42,43]$} \\
\hline Dectin-1 (Clec7A) & Recognizes $\beta$-glucans and can lead to phagocytosis. & Yes & $\begin{array}{l}\text { Observed in human macrophages but unknown } \\
\text { whether it is expressed in human microglia. }\end{array}$ & {$[19,44,45]$} \\
\hline CD301 (MGL1) & $\begin{array}{l}\text { Recognizes terminal galactose and N-acetylgalactosamine. } \\
\text { Involved in pathogen defense and related to CD206. }\end{array}$ & Yes (our observations) & Unknown & [46] \\
\hline
\end{tabular}


to promote killing of any invading organism and remove dead cells to 'clean' the damaged area [62]. This response is then shifted to an anti-inflammatory state where debris clearance, extracellular matrix deposition, and angiogenesis are promoted [24]. Thus, when there is proper transition from the M1 to M2 phenotype, the damage can be efficiently repaired. However, when the proinflammatory response does not yield, the constant presence and continued production of inflammatory cytokines and reactive oxygen species can lead to cell death and further tissue damage [63].

\section{Spinal cord injury}

One of the better-studied areas of M1 and M2 activation in the CNS is after spinal cord injury. Following the initial trauma of spinal cord injury, secondary inflammation has been identified as an important factor that leads to enhanced damage and impaired regeneration. Consistent with this, several M1 microglial secreted factors have been shown to be neurotoxic and inhibit axon extension [63-65]. Kigerl et al. [63] characterized the response of M1 and M2 cells both acutely and several weeks after spinal cord injury. Initially, they observed early upregulation of both M1- and M2-related proteins and mRNA species. However, three days post-injury, the M1 markers continued to rise and M2 markers were downregulated, leading to a skewed M1 profile [63]. Kigerl et al. suggested that the domination of M1 cells might be one of the reasons for continued damage and lack of repair. For example, in the same report, using cultured neurons, IFN $\gamma$-polarized M1-conditioned media was neurotoxic and prevented axon elongation after injury, while IL-4 treated, M2-conditioned media encouraged axon growth [63]. The beneficial functions of IL-4 appear to extend to endogenous IL-4, since IL- $4^{-/}$mice showed increased damage following spinal cord injury [66]. Other groups have observed similar polarization dynamics after spinal cord injury $[67,68]$. The positive effects of M2 cells on spinal cord injury can also be extended to the enzymatic products of Arg1 activity. For example, Cai et al. demonstrated that polyamines were sufficient to block the suppressive effects of myelin and myelin-associated glycoprotein on dorsal root ganglion neuron regeneration [69].

\section{Traumatic brain injury}

As with spinal cord injury, the damaged tissue environment after traumatic brain injury heavily favors activation of proinflammatory M1 microglia [70]. Several studies demonstrating a protective effect of anti-inflammatory treatment indicate that the inflammatory response after trauma contributes to the ensuing damage [71-73]. The aftermath of traumatic brain injury results in a mixed profile of activated microglia and macrophages exhibiting a range of phenotypes [74]. However after one week, just like with spinal cord injury, the concentration of Arg $1^{+}$cells decreased to non-detectable levels [74], and other studies showed the presence of M1 microglia and proinflammatory cytokines weeks to months after traumatic brain injury [74-76]. This suggests that M1 microglia are the dominant phenotype and M2 cells are not present to repair damage. To highlight the importance M2 microglia might play after traumatic brain injury, it was observed in aged mice where the M2 response is impaired (discussed in a later section) that lesion size was increased relative to young animals with a more functional M2 response [70]. The M2 microglia observed during traumatic brain injury do seem to possess beneficial phenotypes that can mitigate damage associated with traumatic brain injury. For example, M2 cells recruited around sites of intracranial hemorrhage after traumatic brain injury expressed the receptor CD163, which functions in hemoglobin scavenging $[39,40,77]$.

\section{Stroke}

Inflammation generated by stroke and ischemic reperfusion injury is regarded as a major factor contributing to tissue damage [60] and, like spinal cord injury, the damaged tissue environment favors an M1 phenotype [78]. In addition to neutrophils, it is these M1 microglia, and, to a lesser degree, macrophages, that contribute to the inflammatory cascade and further propagate cell death beyond the initial ischemic region $[79,80]$. Even though the proinflammatory response is dominant, there does appear to be an anti-inflammatory signal that attempts to regulate the inflammation [78]. Consistent with the idea that an M2 response is needed to properly downregulate inflammation and initiate repair, mice that lack appropriate signals for M2 induction have worse outcomes after experimental cerebral ischemia. For example, mice lacking either IL-4 or IL-10 show increased infarct volume and worse cognitive performance following cerebral ischemia $[81,82]$. Additionally, deletion of galectin-3, a protein required for microglial activation, leads to a reduction in M2-associated cytokines, such as IGF-1, which results in worse pathology after stroke [83]. This highlights the importance of M2 cells in mitigating and repairing damage.

\section{Controlling polarization}

The experiments described above demonstrate the crucial dynamics between M1 and M2 polarization during injury state. One piece of information that comes out of this research is the critical role the environment plays in controlling the shift from classical to alternative activation. With spinal cord injury and traumatic brain injury, the domination of M1 microglia is mainly due to the high levels of proinflammatory cytokines present $[60,68]$. Importantly, polarized microglia are not locked in a particular state; both microglia and macrophages are plastic cell types that can be altered if the cytokine environment changes [84]. 
However, in many acute injuries, the continued production of cytokines like IFN $\gamma$ and TNFo maintains an M1 activation state. One would therefore hypothesize that altering the environment could be used to treat injuries. To that end, in models of the injuries described previously, investigators have begun to utilize techniques to inject M2 cells directly or cause polarization indirectly. In spinal cord injury, the transplantation of mesenchymal stem cells has been shown to increase IL-4/13 and decrease TNF $\alpha$ levels [85]. These cytokine changes were associated with increased $\mathrm{Arg} 1^{+}$staining, consistent with an M2 response, and associated with downregulation of inflammation, locomotor recovery and reduced scar formation [85]. This has been shown in several other cases, where M2 cell induction appeared to alleviate spinal cord injury pathology [86-89]. This beneficial result is not limited to spinal cord injury. By targeting the PPAR $\gamma$ pathway with PPAR $\gamma$ agonists that potentially lead to induction of M2 microglia, several groups have shown efficacy in treating traumatic brain injury [71,72] and ischemia [90]. As summarized in Table 2, there are several other examples of investigators using various molecules that are now known to induce M2 polarization in order to treat CNS injuries.

\section{M2 microglia in chronic neuroinflammation}

As mentioned in the previous section, the inflammatory response needs to be downregulated for proper healing to take place. In contrast with acute inflammation, chronic neuroinflammation is a long-lived, persistent response that starts with an initial inflammatory stimulus, but becomes self-propagating. Inflammatory factors produced by microglia and astrocytes can damage local tissue and, together with released DAMPs, can further increase inflammation and glial activation, leading to a vicious inflammatory cycle. This long-term inflammation can have disastrous consequences in the CNS, ranging from loss of synapses to impaired cognition and overt neurodegeneration [104-107]. This shift away from reparative responses may be due to a failed M2 response. Not only could the lack of M2 microglia fail to control inflammation; fewer M2 cells also mean lower levels of neuroprotective factors like IGF1 or brainderived neurotrophic factor, which microglia produce. Thus the lack of an appropriate M2 response might be an important mechanism underlying neurodegeneration. Indeed, many investigators are starting to recognize the importance of M1/M2 dynamics in diseases characterized by chronic neuroinflammation.

\section{Experimental autoimmune encephalitis (EAE) and multiple sclerosis}

Multiple sclerosis is a disease characterized by demyelination of axons as well as chronic inflammation. Multiple sclerosis exists in several forms; the majority of patients show a relapsing and remitting type of disease. These patients experience demyelination and inflammation but this resolves after some time. This process occurs multiple times during the course of disease, with each subsequent relapse being slightly worse, until they finally progress to secondary progressive multiple sclerosis [108]. The observation that there is resolution suggests that M1/M2 dynamics might be relevant for this disease. Although the initial cause of inflammation is not clear, it has been observed that T cells, specifically Th1 and Th17 cells, are important contributors to multiple sclerosis pathology [109]. As previously stated, Th1 cell-secreted IFNY is a potent inducer of M1 cells, suggesting during the active phase that microglia are skewed towards M1 activation. Although T cells regulate the response, microglia and macrophages are the effector cells. Several groups have begun to examine these dynamics in vivo using the multiple sclerosis animal model experimental autoimmune encephalitis (EAE).

An environment dominated by inflammatory cytokines favors polarization to M1 cells and inhibits an M2 switch. The consequences of this inhibition are not fully understood, but during EAE induction and progression, inflammatory factors have the potential to prevent recovery [110]. Elevated levels of inflammatory cytokines are also observed in human multiple sclerosis [105]. It is believed that inflammation contributes to axonal demyelination owing to neurotoxic cytokine effects on oligodendrocytes or inhibition of oligodendrocyte precursor cell proliferation and maturation [110]. This places M1 cells as key contributors to multiple sclerosis pathogenesis. Indeed, mice lacking IL-4 or IL-4R $\alpha$ showed significantly worse EAE pathology [111]. The importance of IL-4 in EAE is also supported by observations that transduction with an IL-4 expressing viral vector reduced the symptoms of EAE $[93,94]$. Even though IL-4 has actions on other CNS cell types, its most potent effect is the induction of M2 microglia. Additionally, other M2 promoting cytokines, such as IL-33 [98] and IL-10 [96], have been shown to reduce the amount of demyelination [96] and improve clinical scores [98]. It is important to note that these EAE models were of the chronic variety, as opposed to other EAE models that only display a transient pathology. This demonstrates that altering the pro-M1 environment to one more conducive to M2 generation has beneficial effects in chronic diseases (Table 2). The mechanism behind the beneficial effects of M2 cells can be attributed to their production of neurotropic mediators that support remyelination and regeneration. Factors such as IGF1, PDGF $\alpha$, TGF $\beta$, and SPP1 are all upregulated in microglia during the recovery phase of disease [112].

The beneficial effect of environmental modulation favoring M2 polarization can also be seen in human beings. The FDA-approved drug glatiramer acetate (GA), which has been shown to be useful in treating relapsing and remitting multiple sclerosis, works by inducing a Th1 to 
Table 2 M2 inducing agents used in disease models

\begin{tabular}{|c|c|c|}
\hline Disease or injury & Treatment & Outcome \\
\hline Traumatic brain injury & Rosiglitazone & $\begin{array}{l}24 \text { hours after controlled cortical impact, rosiglitazone was given intraperitc } \\
\text { Seven days later there were decreased cortical lesions and reduced glial ac } \\
\text { A reduction in apoptotic cells was also seen. }\end{array}$ \\
\hline Ischemia & Rosiglitazone & $\begin{array}{l}\text { Rosiglitazone was given orally before ischemia was induced. Treatment red } \\
\text { damage in the hippocampal CA1 region and delayed neural death. Elevate } \\
\text { levels of IL-4 and IL-13 were seen after treatment. }\end{array}$ \\
\hline \multirow[t]{2}{*}{ Spinal cord injury } & Rosiglitazone & $\begin{array}{l}\text { Rosiglitazone was injected intraperitoneally every } 12 \text { hours after spinal cord } \\
\text { for } 12 \text { days. Treatment decreased tissue damage and significantly reduced } \\
\text { apoptosis in damaged tissue. TNFa and IL1 } 1 \beta \text { reduction was also observed. }\end{array}$ \\
\hline & $\begin{array}{l}\text { Mesenchymal stem } \\
\text { cell transplantation }\end{array}$ & $\begin{array}{l}\text { Transplantation in an injured spinal cord resulted in elevated levels of IL-4 } \\
\text { and IL-13 and reduced TNFa and IL-6. There was functional locomotion } \\
\text { improvement as well as reduced scarring and more preserved axons. }\end{array}$ \\
\hline
\end{tabular}

Granulocyte colony- Granulocyte colony-stimulating factor was injected for three consecutive days stimulating factor after spinal cord injury. Enhanced Arg1 and CD206 mRNA and reduced iNOS, TNFa, and IL-1 $\beta$ were seen. There was also reduced NF-KB activity. No locomotor tests were performed, but the authors concluded that this is a viable method to reduce acute phase inflammation after spinal cord injury.

Substance $P$

Substance $P$ was injected intravenously immediately, 24, and 48 hours after spinal cord injury. Injected rats had reduced iNOS, IL-6, and TNFa mRNA levels and elevated amounts of Arg1 and IL-10. M2 cells were observed at the lesion site. Spinal cord lesions were significantly smaller and injected mice had improved locomotion scores. mice with EAE. Treatment delayed progression of disease and improved clinical score. Significant reduction in inflammation and axon degeneration was also seen.

IL-4 Used transduced T cells carrying a retroviral gene to express IL-4 during EAE. Mice showed delayed onset and reduced severity of disease.

IL-4 Adenoviral-vector-carrying IL-4 was injected into cerebrospinal fluid of mice induced to have EAE. Reduced clinical score and improvement in several neurophysiological parameters were seen in injected mice.

IL-10 Used adult neural stem cells engineered to express IL-10. Intraperitoneal injection during EAE reduced CNS inflammation and lessened demyelination. Additionally there was enhanced remyelination.

Glatiramer acetate Glatiramer acetate is a synthetic peptide shown to be beneficial in treating relapsing and remitting multiple sclerosis. It shifts the CNS environment from Th1 to Th2 and induces secretion of anti-inflammatory cytokines.

IL-33 Intraperitoneal injection of IL-33, 12-20 days after induction of EAE, reduced inflammatory cytokines and improved clinical scores. Elevated M2 cells were also seen around lesions. APP/PS1 mice. The effect is thought to be mediated in part by glatiramer acetate inducing IL-4, which can counteract the effect of amyloid $\beta$ on microglia. Glatiramer acetate vaccination also reversed cognitive decline.

IL-4 Intracerebral injection of IL-4 and IL-13 reduced amyloid $\beta$ plaque load in APP23 mice with Alzheimer's disease. The decrease was accompanied with improved cognition and upregulation of Arg1 and YM1 positive M2 cells. AAV carrying an IL-4 sequence was injected intrahippocampally in 3-month-old APP/PS1 mice. Five months later there was a reduction in amyloid $\beta$ plaques, improvement in the Morris water maze memory task, and elevated neurogenesis.

AAV expressing IL-10 was injected intrahippocampally in 3-month-old APP/PS1 mice. at 5 months. However, neurogenesis was improved.

DSP-8658 DSP-8658 (a PPAR $\gamma /$ a agonist) treatment was able to increase microglial uptake of amyloid $\beta$ in APP/PS1 mice. The mechanism of action was thought to be via CD36 upregulation on microglia.

Bexarotene $\quad$ Bexarotene (retinoid $X$ receptor agonist) in APP/PS1 and APP/PS1-21 mice with Alzheimer's disease led to reduced amyloid load 14 days after oral treatment. The plaque reduction was associated with improved order habituation behavior.

\footnotetext{
AAV, adeno-associated virus; APP, amyloid precursor protein; CNS, central nervous system; EAE, experimental autoimmune encephalitis.
} 
Th2 shift, resulting in the production of anti-inflammatory cytokines [97]. Even though changing the environment seems to be beneficial in alleviating symptoms for the relapsing and remitting type of multiple sclerosis, the majority of patients ultimately experience progressive disease, suggesting that the environment is not the only factor in controlling inflammation. Since multiple sclerosis is a chronic disease that takes many years to progress, the continuous long-term activation of microglia has the potential to alter microglial function, either by making them less responsive to anti-inflammatory signals or less adept at phagocytosis. This potential failure of microglia to perform their proper function is also shared by other neurodegenerative diseases characterized by persistent, longterm inflammation. One of the best examples of this is Alzheimer's disease.

\section{Alzheimer's disease}

The idea that microglial activation states could impact Alzheimer's disease has recently gained momentum. Alzheimer's disease is the most common form of dementia and is characterized by the presence of neurofibrillar tangles of hyperphosphorylated Tau and extracellular deposits of the peptide amyloid $\beta(A \beta)$, forming neuritic plaques. Another key feature of Alzheimer's disease is the presence of prominent neuroinflammation [113]. Interestingly, A $\beta$ itself has been shown to have proinflammatory properties when injected into the CNS $[114,115]$. Amyloid $\beta$ can bind to several innate immune receptors present on microglia, such as TRL2 [114], TRL4 [116], TLR6 [116], and CD14 [117], all of which can lead to activation when triggered. To that end, microglia surrounding $A \beta$ plaques show elevated production of inflammatory factors [118]. The inflammatory nature of amyloid has been recognized as a potential mechanism of disease progression. Amyloid $\beta$ is generated from a parent protein called the amyloid precursor protein (APP), which is cleaved in two steps by the enzymes $\beta$ then $\gamma$ secretase, leading to release of the $A \beta$ fragment [119]. This is a normal physiological process that is modified in the disease state. Interestingly, inflammation can promote accumulation of A $\beta$ by elevating APP levels and the activity of cleavage enzymes [120]. These observations have led to the inflammatory cascade hypothesis of Alzheimer's disease, which states that $A \beta$ deposition induces neuroinflammation, which in turn generates more $\mathrm{A} \beta$, resulting in a vicious cycle [120].

There are several ways for $A \beta$ to be removed from the brain. Amyloid $\beta$ can be directly shuttled out of the brain via protein complexes such as LRP1 and apolipoprotein E, which can bind extracellular $A \beta$ and transport them to the blood brain barrier, where they are then shuttled to the other side [121]. Additionally, new observations suggest the existence of an alternate removal pathway, where extracellular $A \beta$ in CNS interstitial fluid is moved into the cerebral spinal fluid in what is named the 'glymphatic system' [122]. Another way to clear A $\beta$ is via phagocytosis and degradation by resident CNS immune cells, such as microglia [123], astrocytes [124], and possibly neurons [125]. This particular clearance pathway showcases the Janus face nature of microglia in that even though microglia are a primary source of inflammatory factors, they also represent a crucial element for removal of harmful material in the CNS [123]. Thus, the failure of microglia to carry out homeostatic functions possibly underscores one mechanism of increased $A \beta$ accumulation during disease.

When $A \beta$ is injected into the rat CNS, microglia are observed to contain the injected peptide, demonstrating their ability to take up A $\beta$ [126]. However, in-vitro evidence suggests that this phagocytic ability is inhibited during disease [127]. The ability of microglia to phagocytize $A \beta$ may depend on their phenotype. For example, in-vitro treatment of microglia with the pro M1 activator lipopolysaccharide inhibited microglial phagocytosis of $A \beta$ [127]. Other proinflammatory cytokines, such as IFN $\gamma$ and TNF $\alpha$ not only inhibited uptake of $A \beta$, but also prevented internalized $A \beta$ degradation $[128,129]$. This demonstrates that M1 microglia might be less able to properly take up and degrade $\mathrm{A} \beta$. While M1 microglia appear to be impaired in their ability to remove $A \beta, M 2$ microglia have been demonstrated to be efficient phagocytes. Treatment with the pro M2 activating cytokine IL-4 can effectively block lipopolysaccharideinduced inhibition of $A \beta$ phagocytosis [127] and similar data have been obtained for IL-10 [129]. This effect also extends to degradation of the internalized $A \beta$. Treatment with IL-4 or macrophage colony-stimulating factor can lower the $\mathrm{pH}$ of the phagosome and lysosome and allow for more efficient degradation of A $\beta$ [130,131]. These in-vitro M1 versus M2 observations are further supported by an everincreasing set of in-vivo data, as detailed next.

It appears that one of the reasons for $A \beta$ accumulation in Alzheimer's disease is the failure of microglia to react properly. As mentioned, inflammation limits the phagocytic potential of microglia [127], but does this occur in vivo? Early on in disease pathogenesis, there does seem to be an attempt to clear A $\beta$. Jimenez et al. [132] observed at 6 months, when $A \beta$ begins to accumulate in the APP/ PS1 Alzheimer's disease mouse model, that there were $\mathrm{YM}^{+}$cells present in the CNS; however, by 18 months YM1 mRNA levels decreased and there was a massive upregulation in inflammatory factors, suggesting a switch from M2 to M1 as pathology worsened [132]. This is consistent with the idea that microglia become less responsive to M2 induction signals as they age, perhaps owing to an age-associated decrease in IL-4R $\alpha$ levels [133]. Correspondingly, in older, non-diseased mice there is downregulation of receptors associated with $A \beta$ engulfment, such as scavenger receptor $A$ and the $A \beta$ degradation enzymes Nep, IDE, and MMP-9 [134]. These observations suggest 
that the $A \beta$ induced inflammatory environment, combined with age-associated effects on microglia, lead to a situation where M1 cells predominate and microglia lose the ability to switch phenotypes and mitigate damage.

Several groups have utilized animal models of Alzheimer's disease to demonstrate that altering the microglial activation state can be beneficial (Table 2). As previously mentioned for multiple sclerosis, GA is a promising molecule that can alter the inflammatory environment by recruiting Th2 T cells to the CNS and induce production of IL-4. Since it has shown positive benefits in patients with multiple sclerosis, there is the potential that GA could be a useful Alzheimer's disease treatment. Data from Michal Schwartz's group demonstrated that GA treatment leads to increased $A \beta$ clearance and elevated levels of neurotropic cytokines such as IGF-1 [99]. The phenotype of microglia after treatment was similar to those treated with IL-4, suggesting that the GA effect could be IL-4 (and subsequently M2) dependent [135]. PPARY activation is another approach that can robustly induce the polarization of M2 microglia and may be a promising therapy for Alzheimer's disease. Several groups have observed that prolonged treatment with PPAR $\gamma$ agonists can reduce Alzheimer's disease pathology, demonstrating its potential therapeutic efficacy $[102,136,137]$. In addition to reducing plaques, the PPAR $\gamma$ agonist pioglitazone increased mRNA levels of the M2 marker YM1 [137] as well as the scavenger receptor CD36 [102]. Recently, activation of the retinoid X receptor (RXR), which forms a heterodimer with PPAR $\gamma$, was implicated as a promising therapeutic treatment for Alzheimer's disease. Landreth's group [103] demonstrated that treatment with the FDA-approved RXR agonist bexarotene reduced CNS A $\beta$ levels and improved cognition in an Alzheimer's disease mouse model [103]. Interestingly, PPAR $\gamma$ treatment has been demonstrated to polarize human monocytes to an M2 state [138], which further supports the idea that manipulating proinflammatory M1 microglia to an M2 phenotype is a potentially viable therapeutic option.

In addition to pharmacological methods to induce M2 activation, direct use of anti-inflammatory cytokines can lead to $A \beta$ removal. As previously stated, the definitions for multiple phenotypes of alternatively activated macrophages originate from the periphery and therefore might not be completely applicable to the CNS. However, microglia treated with different anti-inflammatory cytokines exhibit unique activation states and functions. This topic is actively being pursued, in order to better understand differences between states [54]. For the sake of simplicity and a point of reference, we will refer to the activation states that are known for peripheral macrophages. TGF $\beta$ is a cytokine with potent anti-inflammatory properties that polarizes microglia to an M2c phenotype. Importantly, mice overexpressing TGF $\beta$ have reduced plaque loads [139] and mice deficient for TGF $\beta$ signaling showed elevated pathology [140]. In-vitro cultures also confirm that TGF $\beta$ treatment can enhance microglial uptake of $\mathrm{A} \beta$ [141]. Interleukin-4, the prototypic M2 inducing cytokine, has been shown in several cases to mitigate Alzheimer's disease pathology. Acute injection of $100 \mathrm{ng}$ of IL-4 decreased A $\beta$ levels in just a few days [32]. The $A \beta$ decrease was correlated with an increase in pro $A \beta$ phagocytic and degradation enzymes CD36 and neprilysin that colocalized to YM1 and Arg1 ${ }^{+}$ M2 cells. Using an adeno-associated virus type 2 vector to provide sustained IL-4 expression, Kiyota et al. observed a reduction in gliosis, decreased $A \beta$, and improved spatial memory [100]. Interestingly, this same group attempted to replicate these results with IL-10 and only observed an increase in neurogenesis [101]. This discrepancy between M2-inducing cytokines suggests that different subtypes of alternatively activated microglia have unique functions. Interleukin-4-induced M2a microglia seem to be better in terms of engulfing $A \beta$, while IL-10-induced M2c microglia might play more of a supportive function.

Interestingly, and somewhat surprisingly, several groups, using both immunohistochemistry and ELISA as measurements, have observed that injection of inflammatory cytokines can also result in decreased $A \beta$. Work from our laboratory, in which the APP/PS1 Alzheimer's disease mouse [142] was crossed with a mouse that conditionally expressed IL-1 $\beta$, demonstrated that four weeks of sustained inflammation led to decreased $\mathrm{A} \beta$ plaque deposition as opposed to enhanced pathology [143]. Other groups have observed similar effects with different proinflammatory mediators and cytokines, such as lipopolysaccharide, IFN $\gamma$, TNF $\alpha$, and IL-6 [144-147]. At first, this does not seem consistent with the in-vitro observations of inflammatory cytokines impairing $A \beta$ clearance; however, one important distinction is that the in-vitro experiments exist in a closed system. Single treatments with cytokines in vitro impair phagocytic functions of microglia but do not take into account other cells and how they react to the inflammatory state in vivo. As previously mentioned, there is an established pattern of immune cell activation during inflammation. Initially there is a proinflammatory response, which gives way to an anti-inflammatory response that mitigates and repairs damage. Cells capable of secreting Th2 cytokines, such as T cells [148-150] and mast cells $[151,152]$ migrate to the inflamed area and are potential sources of anti-inflammatory cytokines. However, the presence and function of these cells during Alzheimer's disease is still debated. Even though the activity of peripheral cells is not clear, endogenous cells like astrocytes and microglia have been observed to secrete IL-4 or IL-10 during pathological conditions [153]. This important distinction between in-vivo and in-vitro data needs to be kept in context when observing how inflammatory stimuli affect the CNS. 


\section{M2 microglia: always beneficial?}

Not all share the idea that alternatively activated microglia are a beneficial cell type. As was the case with Hortega almost a century ago, the function of microglia is still a debated issue. However, the discussion now centers on the relative contributions of different microglial phenotypes and whether or not they are truly beneficial. Instead of viewing M2 microglia as alternatively activated, some believe that this cell type resembles a deactivated population that actually loses proper function. In a study by Chakrabarty et al. [154], an AAV vector carrying IL-4 was injected into the CNS of the TgCRND8 Alzheimer's disease mouse model. Contrary to previously published studies [100], an increase in amyloid pathology was seen [154]. The authors reasoned that this increase is due to IL-4 inhibiting microglia from properly scavenging $A \beta$. However, exactly why their result is so different from other in-vivo and in-vitro data is unclear.

Additionally, even though downstream products of Arg1 activity have been observed to contribute to wound repair, matrix deposition, and axon regeneration, excess polyamines can trigger inflammation [155] and macrophage recruitment [156], suggesting that Arg1 activity can be proinflammatory. This further highlights the complex nature of alternatively activated microglia and emphasizes the need to view these cells in context rather than assume they are beneficial in all circumstances.

\section{Alternative activation in human beings?}

The recent advances in our understanding of alternatively activated microglia and their potential efficacy in treating disease have led to greater interest in translational human studies. Unfortunately, the leap to human M2 cells is not without its own problems. As noted in Table 1, several commonly used markers, such as Arg1 and YM1 are not expressed in human myeloid cells [33], which limits the ability to identify distinct human microglial phenotypes. However, other markers appear to be consistent. CD163positive cells have been observed in stroke and multiple sclerosis, providing a means to identify M2 microglia in human diseases $[39,157]$. Furthermore, mutations in TREM2, a molecule implicated in both human and murine M2 microglial function, are associated with increased risk of Alzheimer's disease [158]. In relation to this idea, levels of M2-inducing molecules, such as resolvin D1 [21,159] and IL-10, were reduced in patients with Alzheimer's disease [160]. Moreover, resolvin D1 levels significantly correlated with worse Mini-Mental State Examination scores [160], suggesting that the lack of factors to induce M2 polarization has potential functional relevance in human disease. To that end, efforts have been taken to 
examine different populations of M1 or M2 markers in human Alzheimer's disease patients. Using several different mRNAs for M2 markers, two different populations can be identified: Alzheimer's disease brains that are skewed towards M1 and those with an M2a bias [161]. Furthermore, the different populations are associated with different disease stages. In what appears to be early Alzheimer's disease, there is an M1 bias, while patients with later stage Alzheimer's disease have an M2a bias. This suggests a potential functional relevance of different microglia populations. However, whether the transition from M1 to $\mathrm{M} 2 \mathrm{a}$ is related to disease progression or is simply a response to the enhanced pathology is yet to be understood. Obviously, more work is needed to determine just what these populations represent.

\section{Conclusion}

There is compelling evidence that alternatively activated macrophages are not only a vital homeostatic element in the periphery, but that microglia, and perhaps all tissue specific macrophages, also have the capacity for multiple activation states, defined by the environmental milieu in normal and disease conditions. Although considerably more work pertaining to peripheral macrophages has been accomplished, a significant effort has been made to better define microglial activation phenotypes. The notion that there are either 'good' or 'bad' activation states of microglia has lost favor. Rather, there exists a spectrum that spans several different activation types with different functions, as represented in our working model (Figure 1). By understanding the nature of microglial activation states and identifying particular induction signals for select states, we come closer to utilizing such signals as therapeutic tools in pathological conditions where detrimental polarization may contribute to disease.

\section{Abbreviations \\ AAV: adeno-associated virus; A $\beta$ : amyloid $\beta$; APP: amyloid precursor protein; Arg1: arginase 1; CNS: central nervous system; DAMP: damage-associated molecular pattern; EAE: experimental autoimmune encephalomyelitis; ELISA: enzyme-linked immunosorbent assay; GA: glatiramer acetate; IFNy: interferon-y; IL-4: interleukin 4; iNOS: nitric oxide synthase; NOD: nucleotide-binding oligomerization domain; RXR: retinoid $X$ receptor; TLR: toll-like receptor.}

\section{Competing interests}

The authors declare that they have no competing interests.

\section{Authors' contribution}

JDC researched the literature and drafted the manuscript. JAO and MKO critically reviewed and edited the work. All authors read and approved the final manuscript.

\section{Acknowledgements}

The authors thank Colin Combs for critical review of the manuscript. MKO and JAO receive research support from the National Institutes of Health (U19 Al091036, RO1 ES020322, RO1 AG30149) and the National Aeronautics and Space Administration (NNX13AC33G).

\section{Author details}

'Department of Pathology and Laboratory Medicine, University of Rochester School of Medicine and Dentistry, Rochester, NY 14642, USA. ²Department of Neurobiology \& Anatomy, University of Rochester School of Medicine and Dentistry, Rochester, NY 14642, USA.

Received: 14 April 2014 Accepted: 21 May 2014

Published: 3 June 2014

\section{References}

1. Del Rio-Hortega P: El tercer elemento de los centros nerviosos. Bio SoC Esp Biol 1919, 9:69-129.

2. McGeer PL, McGeer EG: History of innate immunity in neurodegenerative disorders. Front Pharmacol 2011, 2:77.

3. Haymaker W, Adams RD: Histology and Histopathology of the Nervous System. Springfield, IL: CC Thomas; 1980:481-559.

4. Nimmerjahn A, Kirchhoff F, Helmchen F: Resting microglial cells are highly dynamic surveillants of brain parenchyma in vivo. Science 2005, 308:1314-1318.

5. Frank-Cannon TC, Alto LT, McAlpine FE, Tansey MG: Does neuroinflammation fan the flame in neurodegenerative diseases? $\mathrm{Mol}$ Neurodegener 2009, 4:47

6. Colton CA: Heterogeneity of microglial activation in the innate immune response in the brain. J Neuroimmune Pharmacol 2009, 4:399-418.

7. Gordon S: Alternative activation of macrophages. Nat Rev Immunol 2003, 3:23-35.

8. Stein M, Keshav S, Harris N, Gordon S: Interleukin 4 potently enhances murine macrophage mannose receptor activity: a marker of alternative immunologic macrophage activation. J Exp Med 1992, 176:287-292.

9. Mosser DM, Edwards JP: Exploring the full spectrum of macrophage activation. Nat Rev Immunol 2008, 8:958-969.

10. Ransohoff RM, Perry VH: Microglial physiology: unique stimuli, specialized responses. Annu Rev Immunol 2009, 27:119-145.

11. Ransohoff RM, Brown MA: Innate immunity in the central nervous system. J Clin Invest 2012, 122:1164-1171.

12. Boche D, Perry VH, Nicoll JA: Review: activation patterns of microglia and their identification in the human brain. Neuropathol Appl Neurobiol 2013, 39:3-18.

13. Mills CD, Kincaid K, Alt JM, Heilman MJ, Hill AM: M-1/M-2 macrophages and the Th1/Th2 paradigm. J Immunol 2000, 164:6166-6173.

14. Nathan CF, Murray HW, Wiebe ME, Rubin BY: Identification of interferon- $\gamma$ as the lymphokine that activates human macrophage oxidative metabolism and antimicrobial activity. J Exp Med 1983, 158:670-689.

15. Suzuki Y, Claflin J, Wang X, Lengi A, Kikuchi T: Microglia and macrophages as innate producers of interferon-gamma in the brain following infection with Toxoplasma gondii. Int J Parasitol 2005, 35:83-90.

16. Kawanokuchi J, Mizuno T, Takeuchi H, Kato H, Wang J, Mitsuma N, Suzumura A: Production of interferon- $\gamma$ by microglia. Mult Scler 2006 12:558-564.

17. Perry $\mathrm{VH}$, Teeling J: Microglia and macrophages of the central nervous system: the contribution of microglia priming and systemic inflammation to chronic neurodegeneration. Semin Immunopathol 2013, 35:601-612.

18. Martinez FO, Helming L, Gordon S: Alternative activation of macrophages: an immunologic functional perspective. Annu Rev Immuno/ 2009, 27:451-483.

19. Taylor PR, Martinez-Pomares L, Stacey M, Lin HH, Brown GD, Gordon S: Macrophage receptors and immune recognition. Annu Rev Immunol 2005, 23:901-944.

20. Skeen MJ, Miller MA, Shinnick TM, Ziegler HK: Regulation of murine macrophage IL-12 production. Activation of macrophages in vivo, restimulation in vitro, and modulation by other cytokines. $J$ Immunol 1996, 156:1196-1206.

21. Mantovani A, Sica A, Sozzani S, Allavena P, Vecchi A, Locati M: The chemokine system in diverse forms of macrophage activation and polarization. Trends Immunol 2004, 25:677-686.

22. MacMicking J, Xie QW, Nathan C: Nitric oxide and macrophage function. Annu Rev Immunol 1997, 15:323-350.

23. Bagasra O, Michaels FH, Zheng YM, Bobroski LE, Spitsin SV, Fu ZF, Tawadros $\mathrm{R}$, Koprowski H: Activation of the inducible form of nitric oxide synthase in the brains of patients with multiple sclerosis. Proc Natl Acad Sci U S A 1995, 92:12041-12045. 
24. Varin A, Gordon S: Alternative activation of macrophages: immune function and cellular biology. Immunobiology 2009, 214:630-641.

25. Munder M, Eichmann K, Moran JM, Centeno F, Soler G, Modolell M: Th1/ Th2-regulated expression of arginase isoforms in murine macrophages and dendritic cells. J Immunol 1999, 163:3771-3777.

26. Munder M: Arginase: an emerging key player in the mammalian immune system. Br J Pharmacol 2009, 158:638-651.

27. Morris SM Jr: Arginine metabolism: boundaries of our knowledge. J Nutr 2007, 137:1602S-1609S.

28. Corraliza IM, Soler G, Eichmann K, Modolell M: Arginase induction by suppressors of nitric oxide synthesis (IL-4, IL-10 and PGE2) in murine bone-marrow-derived macrophages. Biochem Biophys Res Commun 1995, 206:667-673.

29. Chang NC, Hung SI, Hwa KY, Kato I, Chen JE, Liu CH, Chang AC: A macrophage protein, $\mathrm{Ym} 1$, transiently expressed during inflammation is a novel mammalian lectin. J Biol Chem 2001, 276:17497-17506.

30. Hung SI, Chang AC, Kato I, Chang NC: Transient expression of Ym1, a heparin-binding lectin, during developmental hematopoiesis and inflammation. J Leukoc Biol 2002, 72:72-82.

31. Raes G, Noël W, Beschin A, Brys L, de Baetselier P, Hassanzadeh GG: FIZZ1 and $\mathrm{Ym}$ as tools to discriminate between differentially activated macrophages. Dev Immunol 2002, 9:151-159.

32. Kawahara K, Suenobu M, Yoshida A, Koga K, Hyodo A, Ohtsuka H, Kuniyasu A, Tamamaki N, Sugimoto Y, Nakayama H: Intracerebral microinjection of interleukin-4/interleukin-13 reduces $\beta$-amyloid accumulation in the ipsilateral side and improves cognitive deficits in young amyloid precursor protein 23 mice. Neuroscience 2012, 207:243-260.

33. Raes G, Van den Bergh R, De Baetselier P, Ghassabeh GH, Scotton C, Locati M, Mantovani A, Sozzani S: Arginase-1 and Ym1 are markers for murine, but not human, alternatively activated myeloid cells. J Immuno/ 2005, 174:6561. author reply 6561-6562.

34. Holcomb IN, Kabakoff RC, Chan B, Baker TW, Gurney A, Henzel W, Nelson C, Lowman HB, Wright BD, Skelton NJ, Frantz GD, Tumas DB, Peale FV Jr, Shelton DL, Hébert CC: FIZZ1, a novel cysteine-rich secreted protein associated with pulmonary infammation, defines a new gene family. EMBO J 2000, 19:4046-4055.

35. Lee DC, Ruiz CR, Lebson L, Selenica ML, Rizer J, Hunt JB Jr, Rojiani R, Reid P, Kammath S, Nash K, Dickey CA, Gordon M, Morgan D: Aging enhances classical activation but mitigates alternative activation in the central nervous system. Neurobiol Aging 2013, 34:1610-1620.

36. Stahl PD, Ezekowitz RA: The mannose receptor is a pattern recognition receptor involved in host defense. Curr Opin Immunol 1998, 10:50-55.

37. Burudi EM, Regnier-Vigouroux A: Regional and cellular expression of the mannose receptor in the post-natal developing mouse brain. Cell Tissue Res 2001, 303:307-317

38. Durafourt BA, Moore CS, Zammit DA, Johnson TA, Zaguia F, Guiot MC, Bar-Or A, Antel JP: Comparison of polarization properties of human adult microglia and blood-derived macrophages. Glia 2012, 60:717-727.

39. Zhang Z, Zhang ZY, Wu Y, Schluesener HJ: Lesional accumulation of $\mathrm{CD}_{163^{+}}$macrophages/microglia in rat traumatic brain injury. Brain Res 2012, 1461:102-110

40. Kowal K, Silver R, Slawinska E, Bielecki M, Chyczewski L, Kowal-Bielecka O: CD163 and its role in inflammation. Folia Histochem Cytobiol 2011, 49:365-374.

41. Roberts ES, Masliah E, Fox HS: CD163 identifies a unique population of ramified microglia in HIV encephalitis (HIVE). J Neuropathol Exp Neurol 2004, 63:1255-1264.

42. Neumann $\mathrm{H}$, Takahashi $\mathrm{K}$ : Essential role of the microglial triggering receptor expressed on myeloid cells-2 (TREM2) for central nervous tissue immune homeostasis. J Neuroimmunol 2007, 184:92-99.

43. Sessa G, Podini P, Mariani M, Meroni A, Spreafico R, Sinigaglia F, Colonna M, Panina P, Meldolesi J: Distribution and signaling of TREM2/DAP12, the receptor system mutated in human polycystic lipomembraneous osteodysplasia with sclerosing leukoencephalopathy dementia. Eur J Neurosci 2004, 20:2617-2628.

44. Willment JA, Lin HH, Reid DM, Taylor PR, Williams DL, Wong SY, Gordon S, Brown GD: Dectin-1 expression and function are enhanced on alternatively activated and GM-CSF-treated macrophages and are negatively regulated by IL-10, dexamethasone, and lipopolysaccharide. J Immunol 2003, 171:4569-4573.

45. Shah VB, Huang Y, Keshwara R, Ozment-Skelton T, Williams DL, Keshvara L: $\beta$-glucan activates microglia without inducing cytokine production in dectin-1-dependent manner. J Immunol 2008, 180:2777-2785.
46. Saba K, Denda-Nagai K, Irimura T: A C-type lectin MGL1/CD301a plays an anti-inflammatory role in murine experimental colitis. Am J Pathol 2009, 174:144-152.

47. Gadani SP, Cronk JC, Norris GT, Kipnis J: IL-4 in the brain: a cytokine to remember. J Immunol 2012, 189:4213-4219.

48. Sica A, Mantovani A: Macrophage plasticity and polarization: in vivo veritas. J Clin Invest 2012, 122:787-795.

49. Martinez FO, Sica A, Mantovani A, Locati M: Macrophage activation and polarization. Front Biosci 2008, 13:453-461.

50. Edwards JP, Zhang X, Frauwirth KA, Mosser DM: Biochemical and functional characterization of three activated macrophage populations. J Leukoc Biol 2006, 80:1298-1307.

51. Filardy AA, Pires DR, Nunes MP, Takiya CM, Freire-de-Lima CG, RibeiroGomes FL, DosReis GA: Proinflammatory clearance of apoptotic neutrophils induces an IL-12(low)IL-10(high) regulatory phenotype in macrophages. J Immunol 2010, 185:2044-2050.

52. Mantovani A, Biswas SK, Galdiero MR, Sica A, Locati M: Macrophage plasticity and polarization in tissue repair and remodelling. J Pathol 2012, 229:176-185.

53. Biswas SK, Mantovani A: Macrophage plasticity and interaction with lymphocyte subsets: cancer as a paradigm. Nat Immuno/ 2010, 11:889-896.

54. Sudduth TL, Schmitt FA, Nelson PT, Wilcock DM: Neuroinflammatory phenotype in early Alzheimer's disease. Neurobiol Aging 2013, 34:1051-1059.

55. Galea I, Palin K, Newman TA, Van Rooijen N, Perry VH, Boche D: Mannose receptor expression specifically reveals perivascular macrophages in normal, injured, and diseased mouse brain. Glia 2005, 49:375-384.

56. Kierdorf K, Erny D, Goldmann T, Sander V, Schulz C, Perdiguero EG, Wieghofer P, Heinrich A, Riemke P, Hölscher C, Müller DN, Luckow B, Brocker T, Debowski K, Fritz G, Opdenakker G, Diefenbach A, Biber K, Heikenwalder M, Geissmann F, Rosenbauer F, Prinz M: Microglia emerge from erythromyeloid precursors via Pu.1- and Irf8-dependent pathways. Nat Neurosci 2013, 16:273-280.

57. Schulz C, Gomez Perdiguero E, Chorro L, Szabo-Rogers H, Cagnard N, Kierdorf K, Prinz M, Wu B, Jacobsen SE, Pollard JW, Frampton J, Liu KJ, Geissmann F: A lineage of myeloid cells independent of Myb and hematopoietic stem cells. Science 2012, 336:86-90.

58. Fleming JC, Norenberg MD, Ramsay DA, Dekaban GA, Marcillo AE, Saenz $A D$, Pasquale-Styles M, Dietrich WD, Weaver LC: The cellular inflammatory response in human spinal cords after injury. Brain 2006, 129:3249-3269.

59. Kigerl KA, Popovich PG: Toll-like receptors in spinal cord injury. Curr Top Microbiol Immunol 2009, 336:121-136.

60. Moskowitz MA, Lo EH, ladecola C: The science of stroke: mechanisms in search of treatments. Neuron 2010, 67:181-198.

61. Lucas T, Waisman A, Ranjan R, Roes J, Krieg T, Muller W, Roers A, Eming SA: Differential roles of macrophages in diverse phases of skin repair. $J$ Immunol 2010, 184:3964-3977.

62. Soehnlein O, Lindbom L: Phagocyte partnership during the onset and resolution of inflammation. Nat Rev Immunol 2010, 10:427-439.

63. Kigerl KA, Gensel JC, Ankeny DP, Alexander JK, Donnelly DJ, Popovich PG: Identification of two distinct macrophage subsets with divergent effects causing either neurotoxicity or regeneration in the injured mouse spinal cord. J Neurosci 2009, 29:13435-13444.

64. Bao F, Bailey CS, Gurr KR, Bailey SI, Rosas-Arellano MP, Dekaban GA, Weaver LC: Increased oxidative activity in human blood neutrophils and monocytes after spinal cord injury. Exp Neurol 2009, 215:308-316.

65. Horn KP, Busch SA, Hawthorne AL, van Rooijen N, Silver J: Another barrier to regeneration in the CNS: activated macrophages induce extensive retraction of dystrophic axons through direct physical interactions. J Neurosci 2008, 28:9330-9341.

66. Lee SI, Jeong SR, Kang YM, Han DH, Jin BK, Namgung U, Kim BG: Endogenous expression of interleukin-4 regulates macrophage activation and confines cavity formation after traumatic spinal cord injury. J Neurosci Res 2010, 88:2409-2419.

67. Thawer SG, Mawhinney L, Chadwick K, de Chickera SN, Weaver LC, Brown A, Dekaban GA: Temporal changes in monocyte and macrophage subsets and microglial macrophages following spinal cord injury in the lys-egfpki mouse model. J Neuroimmunol 2013, 261:7-20.

68. David S, Kroner A: Repertoire of microglial and macrophage responses after spinal cord injury. Nat Rev Neurosci 2011, 12:388-399.

69. Cai D, Deng K, Mellado W, Lee J, Ratan RR, Filbin MT: Arginase I and polyamines act downstream from cyclic AMP in overcoming inhibition of axonal growth MAG and myelin in vitro. Neuron 2002, 35:711-719. 
70. Kumar A, Stoica BA, Sabirzhanov B, Burns MP, Faden Al, Loane DJ: Traumatic brain injury in aged animals increases lesion size and chronically alters microglial/macrophage classical and alternative activation states. Neurobiol Aging 2013, 34:1397-1411.

71. Qi L, Jacob A, Wang P, Wu R: Peroxisome proliferator activated receptor- $\gamma$ and traumatic brain injury. Int J Clin Exp Med 2010, 3:283-292.

72. Yi JH, Park SW, Brooks N, Lang BT, Vemuganti R: PPARy agonist rosiglitazone is neuroprotective after traumatic brain injury via anti-inflammatory and anti-oxidative mechanisms. Brain Res 2008, 1244:164-172.

73. Haber M, Abdel Baki SG, Grin'kina NM, Irizarry R, Ershova A, Orsi S, Grill RJ, Dash P, Bergold PJ: Minocycline plus N-acetylcysteine synergize to modulate inflammation and prevent cognitive and memory deficits in a rat model of mild traumatic brain injury. Exp Neurol 2013, 249:169-177.

74. Hsieh CL, Kim CC, Ryba BE, Niemi EC, Bando JK, Locksley RM, Liu J, Nakamura MC, Seaman WE: Traumatic brain injury induces macrophage subsets in the brain. Eur J Immunol 2013, 43:2010-2022.

75. Breunig JJ, Guillot-Sestier MV, Town T: Brain injury, neuroinflammation and Alzheimer's disease. Front Aging Neurosci 2013, 5:26.

76. Frugier T, Morganti-Kossmann MC, O'Reilly D, McLean CA: In situ detection of inflammatory mediators in post mortem human brain tissue after traumatic injury. J Neurotrauma 2010, 27:497-507.

77. Akila P, Prashant V, Suma MN, Prashant SN, Chaitra TR: CD163 and its expanding functional repertoire. Clin Chim Acta 2012, 413:669-674.

78. Hu X, Li P, Guo Y, Wang H, Leak RK, Chen S, Gao Y, Chen J: Microglia/ macrophage polarization dynamics reveal novel mechanism of injury expansion after focal cerebral ischemia. Stroke 2012, 43:3063-3070.

79. Denker SP, Ji SQ, Dingman A, Lee SY, Derugin N, Wendland MF, Vexler ZS: Macrophages are comprised of resident brain microglia not infiltrating peripheral monocytes acutely after neonatal stroke. J Neurochem 2007, 100:893-904.

80. Schilling M, Besselmann M, Muller M, Strecker JK, Ringelstein EB, Kiefer R: Predominant phagocytic activity of resident microglia over hematogenous macrophages following transient focal cerebral ischemia: an investigation using green fluorescent protein transgenic bone marrow chimeric mice. Exp Neurol 2005, 196:290-297.

81. Perez-de Puig I, Miro F, Salas-Perdomo A, Bonfill-Teixidor E, Ferrer-Ferrer M, Marquez-Kisinousky L, Planas AM: IL-10 deficiency exacerbates the brain inflammatory response to permanent ischemia without preventing resolution of the lesion. J Cereb Blood Flow Metab 2013, 33:1955-1966.

82. Xiong $X$, Barreto GE, Xu L, Ouyang YB, Xie X, Giffard RG: Increased brain injury and worsened neurological outcome in interleukin-4 knockout mice after transient focal cerebral ischemia. Stroke 2011, 42:2026-2032.

83. Lalancette-Hebert M, Swarup V, Beaulieu JM, Bohacek I, Abdelhamid E, Weng YC, Sato S, Kriz J: Galectin-3 is required for resident microglia activation and proliferation in response to ischemic injury. J Neurosci 2012, 32:10383-10395.

84. Davis MJ, Tsang TM, Qiu Y, Dayrit JK, Freij JB, Huffnagle GB, Olszewski MA: Macrophage M1/M2 polarization dynamically adapts to changes in cytokine microenvironments in Cryptococcus neoformans infection. MBio 2013, 4:e00264-13.

85. Nakajima H, Uchida K, Guerrero AR, Watanabe S, Sugita D, Takeura N, Yoshida A, Long G, Wright KT, Johnson WE, Baba H: Transplantation of mesenchymal stem cells promotes an alternative pathway of macrophage activation and functional recovery after spinal cord injury. J Neurotrauma 2012, 29:1614-1625.

86. Shechter R, Miller O, Yovel G, Rosenzweig N, London A, Ruckh J, Kim KW, Klein E, Kalchenko V, Bendel P, Lira SA, Jung S, Schwartz M: Recruitment of beneficial M2 macrophages to injured spinal cord is orchestrated by remote brain choroid plexus. Immunity 2013, 38:555-569.

87. Guerrero AR, Uchida K, Nakajima H, Watanabe S, Nakamura M, Johnson WE, Baba $\mathrm{H}$ : Blockade of interleukin- 6 signaling inhibits the classic pathway and promotes an alternative pathway of macrophage activation after spinal cord injury in mice. J Neuroinflammation 2012, 9:40.

88. Sato A, Ohtaki H, Tsumuraya T, Song D, Ohara K, Asano M, Iwakura Y, Atsumi T, Shioda S: Interleukin-1 participates in the classical and alternative activation of microglia/macrophages after spinal cord injury. J Neuroinflammation 2012, 9:65.

89. Guo Y, Zhang H, Yang J, Liu S, Bing L, Gao J, Hao A: Granulocyte colonystimulating factor improves alternative activation of microglia under microenvironment of spinal cord injury. Neuroscience 2013, 238:1-10.
90. Lee $\mathrm{CH}$, Park OK, Yoo KY, Byun K, Lee B, Choi JH, Hwang IK, Kim YM, Won MH: The role of peroxisome proliferator-activated receptor $\gamma$, and effects of its agonist, rosiglitazone, on transient cerebral ischemic damage. J Neurol Sci 2011, 300:120-129.

91. Zhang Q, Hu W, Meng B, Tang T: PPARy agonist rosiglitazone is neuroprotective after traumatic spinal cord injury via anti-inflammatory in adult rats. Neurol Res 2010, 32:852-859.

92. Jiang MH, Chung E, Chi GF, Ahn W, Lim JE, Hong HS, Kim DW, Choi H, Kim J, Son Y: Substance $P$ induces M2-type macrophages after spinal cord injury. Neuroreport 2012, 23:786-792.

93. Furlan R, Poliani PL, Galbiati F, Bergami A, Grimaldi LM, Comi G, Adorini L, Martino G: Central nervous system delivery of interleukin 4 by a nonreplicative herpes simplex type 1 viral vector ameliorates autoimmune demyelination. Hum Gene Ther 1998, 9:2605-2617.

94. Shaw MK, Lorens JB, Dhawan A, DalCanto R, Tse HY, Tran AB, Bonpane C, Eswaran SL, Brocke S, Sarvetnick N, Steinman L, Nolan GP, Fathman CG: Local delivery of interleukin 4 by retrovirus-transduced T lymphocytes ameliorates experimental autoimmune encephalomyelitis. $J$ Exp Med 1997, 185:1711-1714.

95. Butti E, Bergami A, Recchia A, Brambilla E, Del Carro U, Amadio S, Cattalini A, Esposito M, Stornaiuolo A, Comi G, Pluchino S, Mavilio F, Martino G, Furlan R: IL4 gene delivery to the CNS recruits regulatory $T$ cells and induces clinical recovery in mouse models of multiple sclerosis. Gene Ther 2008, 15:504-515.

96. Yang J, Jiang Z, Fitzgerald DC, Ma C, Yu S, Li H, Zhao Z, Li Y, Ciric B, Curtis M, Rostami A, Zhang GX: Adult neural stem cells expressing IL-10 confer potent immunomodulation and remyelination in experimental autoimmune encephalitis. J Clin Invest 2009, 119:3678-3691.

97. Schrempf W, Ziemssen T: Glatiramer acetate: mechanisms of action in multiple sclerosis. Autoimmun Rev 2007, 6:469-475.

98. Jiang HR, Milovanović M, Allan D, Niedbala W, Besnard AG, Fukada SY, Alves-Filho JC, Togbe D, Goodyear CS, Linington C, Xu D, Lukic ML, Liew FY: IL-33 attenuates EAE by suppressing IL-17 and IFN- $\gamma$ production and inducing alternatively activated macrophages. Eur J Immunol 2012, 42:1804-1814.

99. Butovsky O, Koronyo-Hamaoui M, Kunis G, Ophir E, Landa G, Cohen H, Schwartz M: Glatiramer acetate fights against Alzheimer's disease by inducing dendritic-like microglia expressing insulin-like growth factor 1 . Proc Natl Acad Sci U S A 2006, 103:11784-11789.

100. Kiyota T, Okuyama S, Swan RJ, Jacobsen MT, Gendelman HE, Ikezu T: CNS expression of anti-inflammatory cytokine interleukin-4 attenuates Alzheimer's disease-like pathogenesis in APP + PS1 bigenic mice. Faseb J 2010, 24:3093-3102

101. Kiyota T, Ingraham KL, Swan RJ, Jacobsen MT, Andrews SJ, Ikezu T: AAV serotype 2/1-mediated gene delivery of anti-inflammatory interleukin-10 enhances neurogenesis and cognitive function in APP + PS1 mice. Gene Ther 2012, 19:724-733.

102. Yamanaka M, Ishikawa T, Griep A, Axt D, Kummer MP, Heneka MT: PPARy/ RXRa-induced and CD36-mediated microglial amyloid- $\beta$ phagocytosis results in cognitive improvement in amyloid precursor protein/presenilin 1 mice. J Neurosci 2012, 32:17321-17331.

103. Cramer PE, Cirrito JR, Wesson DW, Lee CY, Karlo JC, Zinn AE, Casali BT, Restivo JL, Goebel WD, James MJ, Brunden KR, Wilson DA, Landreth GE: ApoE-directed therapeutics rapidly clear $\beta$-amyloid and reverse deficits in AD mouse models. Science 2012, 335:1503-1506.

104. Rao JS, Kellom M, Kim HW, Rapoport SI, Reese EA: Neuroinflammation and synaptic loss. Neurochem Res 2012, 37:903-910.

105. Amor S, Puentes F, Baker D, van der Valk P: Inflammation in neurodegenerative diseases. Immunology 2010, 129:154-169.

106. Hein AM, O'Banion MK: Neuroinflammation and memory: the role of prostaglandins. Mol Neurobiol 2009, 40:15-32.

107. Kohman RA, Rhodes JS: Neurogenesis, inflammation and behavior. Brain Behav Immun 2013, 27:22-32

108. Antel J, Antel S, Caramanos Z, Arnold DL, Kuhlmann T: Primary progressive multiple sclerosis: part of the MS disease spectrum or separate disease entity? Acta Neuropathol 2012, 123:627-638.

109. Jadidi-Niaragh F, Mirshafiey A: Th17 cell, the new player of neuroinflammatory process in multiple sclerosis. Scand J Immunol 2011, 74:1-13.

110. Tanner DC, Cherry JD, Mayer-Proschel M: Oligodendrocyte progenitors reversibly exit the cell cycle and give rise to astrocytes in response to interferon- $\gamma$. J Neurosci 2011, 31:6235-6246. 
111. Ponomarev ED, Maresz K, Tan Y, Dittel BN: CNS-derived interleukin-4 is essential for the regulation of autoimmune inflammation and induces a state of alternative activation in microglial cells. J Neurosci 2007, 27:10714-10721.

112. Olah M, Amor S, Brouwer N, Vinet J, Eggen B, Biber K, Boddeke HW: Identification of a microglia phenotype supportive of remyelination. Glia 2012, 60:306-321.

113. Akiyama H, Barger S, Barnum S, Bradt B, Bauer J, Cole GM, Cooper NR, Eikelenboom P, Emmerling M, Fiebich BL, Finch CE, Frautschy S, Griffin WS, Hampel H, Hull M, Landreth G, Lue L, Mrak R, Mackenzie IR, McGeer PL, O'Banion MK, Pachter J, Pasinetti G, Plata-Salaman C, Rogers J, Rydel R, Shen Y, Streit W, Strohmeyer R, Tooyoma I, et al: Inflammation and Alzheimer's disease. Neurobiol Aging 2000, 21:383-421.

114. Liu S, Liu Y, Hao W, Wolf L, Kiliaan AJ, Penke B, Rübe CE, Walter J, Heneka MT, Hartmann T, Menger MD, Fassbender K: TLR2 is a primary receptor for Alzheimer's amyloid $\beta$ peptide to trigger neuroinflammatory activation. $\mathrm{J}$ Immunol 2012, 188:1098-1107.

115. Wirz KT, Bossers K, Stargardt A, Kamphuis W, Swaab DF, Hol EM, Verhaagen J: Cortical beta amyloid protein triggers an immune response, but no synaptic changes in the APPswe/PS1dE9 Alzheimer's disease mouse model. Neurobiol Aging 2013, 34:1328-1342.

116. Stewart CR, Stuart LM, Wilkinson K, van Gils JM, Deng J, Halle A, Rayner KJ, Boyer L, Zhong R, Frazier WA, Lacy-Hulbert A, El Khoury J, Golenbock DT, Moore $\mathrm{KJ}$ : CD36 ligands promote sterile inflammation through assembly of a toll-like receptor 4 and 6 heterodimer. Nat Immunol 2010, 11:155-161.

117. Landreth GE, Reed-Geaghan EG: Toll-like receptors in Alzheimer's disease. Curr Top Microbiol Immunol 2009, 336:137-153.

118. Griffin WS, Sheng JG, Roberts GW, Mrak RE: Interleukin-1 expression in different plaque types in Alzheimer's disease: significance in plaque evolution. J Neuropathol Exp Neurol 1995, 54:276-281.

119. Chow W, Mattson MP, Wong PC, Gleichmann M: An overview of APP processing enzymes and products. Neuromolecular Med 2010, 12:1-12

120. Karran E, Mercken M, De Strooper B: The amyloid cascade hypothesis for Alzheimer's disease: an appraisal for the development of therapeutics. Nat Rev Drug Discov 2011, 10:698-712.

121. Zlokovic BV, Deane R, Sagare AP, Bell RD, Winkler EA: Low-density lipoprotein receptor-related protein-1: a serial clearance homeostatic mechanism controlling Alzheimer's amyloid $\beta$-peptide elimination from the brain. J Neurochem 2010, 115:1077-1089.

122. Xie L, Kang $H, X u$ Q, Chen MJ, Liao Y, Thiyagarajan M, O'Donnell J, Christensen DJ, Nicholson C, Iliff JJ, Takano T, Deane R, Nedergaard M: Sleep drives metabolite clearance from the adult brain. Science 2013, 342:373-377.

123. Lee $C Y$, Landreth GE: The role of microglia in amyloid clearance from the AD brain. J Neural Transm 2010, 117:949-960.

124. Yang W, Wu Q, Yuan C, Gao J, Xiao M, Gu M, Ding J, Hu G: Aquaporin-4 mediates astrocyte response to $\beta$-amyloid. Mol Cell Neurosci 2012, 49:406-414.

125. Kanekiyo T, Cirrito JR, Liu CC, Shinohara M, Li J, Schuler DR, Shinohara M, Holtzman DM, Bu G: Neuronal clearance of amyloid- $\beta$ by endocytic receptor LRP1. J Neurosci 2013, 33:19276-19283.

126. Weldon DT, Rogers SD, Ghilardi JR, Finke MP, Cleary JP, O'Hare E, Esler WP, Maggio JE, Mantyh PW: Fibrillar $\beta$-amyloid induces microglial phagocytosis, expression of inducible nitric oxide synthase, and loss of a select population of neurons in the rat CNS in vivo. J Neurosci 1998, 18:2161-2173.

127. Koenigsknecht-Talboo J, Landreth GE: Microglial phagocytosis induced by fibrillar $\beta$-amyloid and IgGs are differentially regulated by proinflammatory cytokines. J Neurosci 2005, 25:8240-8249.

128. Yamamoto M, Kiyota T, Walsh SM, Liu J, Kipnis J, Ikezu T: Cytokinemediated inhibition of fibrillar amyloid- $\beta$ peptide degradation by human mononuclear phagocytes. J Immunol 2008, 181:3877-3886.

129. Michelucci A, Heurtaux T, Grandbarbe L, Morga E, Heuschling P: Characterization of the microglial phenotype under specific proinflammatory and anti-inflammatory conditions: effects of oligomeric and fibrillar amyloid- $\beta$. J Neuroimmunol 2009, 210:3-12.

130. Balce DR, Li B, Allan ER, Rybicka JM, Krohn RM, Yates RM: Alternative activation of macrophages by IL-4 enhances the proteolytic capacity of their phagosomes through synergistic mechanisms. Blood 2011, 118:4199-4208.

131. Majumdar A, Cruz D, Asamoah N, Buxbaum A, Sohar I, Lobel P, Maxfield FR Activation of microglia acidifies lysosomes and leads to degradation of Alzheimer amyloid fibrils. Mol Bio/ Cell 2007, 18:1490-1496.
132. Jimenez S, Baglietto-Vargas D, Caballero C, Moreno-Gonzalez I, Torres M, Sanchez-Varo R, Ruano D, Vizuete M, Gutierrez A, Vitorica J: Inflammatory response in the hippocampus of PS1M146L/APP751SL mouse model of Alzheimer's disease: age-dependent switch in the microglial phenotype from alternative to classic. J Neurosci 2008, 28:11650-11661.

133. Fenn AM, Henry CJ, Huang Y, Dugan A, Godbout JP: Lipopolysaccharideinduced interleukin (IL)-4 receptor- $a$ expression and corresponding sensitivity to the M2 promoting effects of IL-4 are impaired in microglia of aged mice. Brain Behav Immun 2012, 26:766-777.

134. Hickman SE, Allison EK, El Khoury J: Microglial dysfunction and defective $\beta$-amyloid clearance pathways in aging Alzheimer's disease mice. J Neurosci 2008, 28:8354-8360.

135. Butovsky O, Bukshpan S, Kunis G, Jung S, Schwartz M: Microglia can be induced by IFN- $\gamma$ or IL-4 to express neural or dendritic-like markers. Mol Cell Neurosci 2007, 35:490-500.

136. Escribano L, Simon AM, Gimeno E, Cuadrado-Tejedor M, Lopez De Maturana R, Garcia-Osta A, Ricobaraza A, Perez-Mediavilla A, Del Rio J, Frechilla D: Rosiglitazone rescues memory impairment in Alzheimer's transgenic mice: mechanisms involving a reduced amyloid and tau pathology. Neuropsychopharmacology 2010, 35:1593-1604.

137. Mandrekar-Colucci S, Karlo JC, Landreth GE: Mechanisms underlying the rapid peroxisome proliferator-activated receptor- $\gamma$-mediated amyloid clearance and reversal of cognitive deficits in a murine model of Alzheimer's disease. J Neurosci 2012, 32:10117-10128.

138. Bouhlel MA, Derudas B, Rigamonti E, Dièvart R, Brozek J, Haulon S, Zawadzki C, Jude B, Torpier G, Marx N, Staels B, Chinetti-Gbaguidi G: PPARy activation primes human monocytes into alternative $M 2$ macrophages with anti-inflammatory properties. Cell Metab 2007, 6:137-143.

139. Wyss-Coray T, Lin C, Yan F, Yu GQ, Rohde M, McConlogue L, Masliah E, Mucke L: TGF- $\beta 1$ promotes microglial amyloid- $\beta$ clearance and reduces plaque burden in transgenic mice. Nat Med 2001, 7:612-618.

140. Tesseur I, Zou K, Esposito L, Bard F, Berber E, Can JV, Lin AH, Crews L, Tremblay P, Mathews P, Mucke L, Masliah E, Wyss-Coray T: Deficiency in neuronal TGF- $\beta$ signaling promotes neurodegeneration and Alzheimer's pathology. J Clin Invest 2006, 116:3060-3069.

141. Tichauer JE, von Bernhardi R: Transforming growth factor- $\beta$ stimulates $\beta$ amyloid uptake by microglia through Smad3-dependent mechanisms. J Neurosci Res 2012, 90:1970-1980.

142. Reiserer RS, Harrison FE, Syverud DC, McDonald MP: Impaired spatial learning in the $\mathrm{APP}_{\text {Swe }}+\mathrm{PSEN1} \triangle \mathrm{E} 9$ bigenic mouse model of Alzheimer's disease. Genes Brain Behav 2007, 6:54-65.

143. Matousek SB, Ghosh S, Shaftel SS, Kyrkanides S, Olschowka JA, O'Banion MK: Chronic IL-1 $\beta$-mediated neuroinflammation mitigates amyloid pathology in a mouse model of Alzheimer's disease without inducing overt neurodegeneration. J Neuroimmune Pharmacol 2012, 7:156-164.

144. Chakrabarty P, Herring A, Ceballos-Diaz C, Das P, Golde TE: Hippocampal expression of murine TNFa results in attenuation of amyloid deposition in vivo. Mol Neurodegener 2011, 6:16.

145. Chakrabarty P, Ceballos-Diaz C, Beccard A, Janus C, Dickson D, Golde TE, Das P: IFN- $\gamma$ promotes complement expression and attenuates amyloid plaque deposition in amyloid $\beta$ precursor protein transgenic mice. J Immunol 2010, 184:5333-5343.

146. Chakrabarty P, Jansen-West K, Beccard A, Ceballos-Diaz C, Levites Y, Verbeeck C, Zubair AC, Dickson D, Golde TE, Das P: Massive gliosis induced by interleukin- 6 suppresses $A \beta$ deposition in vivo: evidence against inflammation as a driving force for amyloid deposition. Faseb J 2010, 24:548-559.

147. DiCarlo G, Wilcock D, Henderson D, Gordon M, Morgan D: Intrahippocampal LPS injections reduce A $\beta$ load in APP + PS1 transgenic mice. Neurobiol Aging 2001, 22:1007-1012.

148. Baruch K, Schwartz M: CNS-specific T cells shape brain function via the choroid plexus. Brain Behav Immun 2013, 34:11-16.

149. Czirr E, Wyss-Coray T: The immunology of neurodegeneration. J Clin Invest 2012, 122:1156-1163.

150. Denney L, Kok WL, Cole SL, Sanderson S, McMichael AJ, Ho LP: Activation of invariant NKT cells in early phase of experimental autoimmune encephalomyelitis results in differentiation of Ly6C $C^{\text {hi }}$ inflammatory monocyte to M2 macrophages and improved outcome. J Immuno/ 2012, 189:551-557.

151. Lindsberg PJ, Strbian D, Karjalainen-Lindsberg ML: Mast cells as early responders in the regulation of acute blood-brain barrier changes after cerebral ischemia and hemorrhage. J Cereb Blood Flow Metab 2010, 30:689-702. 
152. Nelissen S, Lemmens E, Geurts N, Kramer P, Maurer M, Hendriks J, Hendrix S: The role of mast cells in neuroinflammation. Acta Neuropathol 2013, 125:637-650.

153. Hulshof S, Montagne L, De Groot CJ, Van Der Valk P: Cellular localization and expression patterns of interleukin-10, interleukin-4, and their receptors in multiple sclerosis lesions. Glia 2002, 38:24-35.

154. Chakrabarty P, Tianbai L, Herring A, Ceballos-Diaz C, Das P, Golde TE: Hippocampal expression of murine IL-4 results in exacerbation of amyloid deposition. Mol Neurodegener 2012, 7:36.

155. Soulet D, Rivest S: Polyamines play a critical role in the control of the innate immune response in the mouse central nervous system. I Cell Biol 2003, 162:257-268.

156. Puntambekar SS, Davis DS, Hawel L 3rd, Crane J, Byus CV, Carson MJ: LPSinduced CCL2 expression and macrophage influx into the murine central nervous system is polyamine-dependent. Brain Behav Immun 2011, 25:629-639.

157. Vogel DY, Vereyken EJ, Glim JE, Heijnen PD, Moeton M, van der Valk $P$, Amor S, Teunissen CE, van Horssen J, Dijkstra CD: Macrophages in inflammatory multiple sclerosis lesions have an intermediate activation status. J Neuroinflammation 2013, 10:35.

158. Guerreiro R, Wojtas A, Bras J, Carrasquillo M, Rogaeva E, Majounie E, Cruchaga C, Sassi C, Kauwe JS, Younkin S, Hazrati L, Collinge J, Pocock J, Lashley T, Williams J, Lambert JC, Amouyel P, Goate A, Rademakers R, Morgan K, Powell J, St George-Hyslop P, Singleton A, Hardy J, Alzheimer Genetic Analysis Group: TREM2 variants in Alzheimer's disease. N Engl $\int$ Med 2013, 368:117-127.

159. Hsiao HM, Sapinoro RE, Thatcher TH, Croasdell A, Levy EP, Fulton RA, Olsen KC, Pollock SJ, Serhan CN, Phipps RP, Sime PJ: A novel anti-inflammatory and pro-resolving role for resolvin D1 in acute cigarette smoke-induced lung inflammation. PLoS One 2013, 8:e58258.

160. Wang X, Zhu M, Hjorth E, Cortés-Toro V, Eyjolfsdottir H, Graff C, Nennesmo I, Palmblad J, Eriksdotter M, Sambamurti K, Fitzgerald JM, Serhan CN, Granholm AC, Schultzberg M: Resolution of inflammation is altered in Alzheimer's disease. Alzheimers Dement 2014, 10.1016/j.jalz.2013.12.024.

161. Wilcock DM: Neuroinflammatory phenotypes and their roles in Alzheimer's disease. Neurodegener Dis 2014, 13:183-185.

doi:10.1186/1742-2094-11-98

Cite this article as: Cherry et al.: Neuroinflammation and M2 microglia: the good, the bad, and the inflamed. Journal of Neuroinflammation 2014 11:98

\section{Submit your next manuscript to BioMed Central and take full advantage of:}

- Convenient online submission

- Thorough peer review

- No space constraints or color figure charges

- Immediate publication on acceptance

- Inclusion in PubMed, CAS, Scopus and Google Scholar

- Research which is freely available for redistribution 